\title{
THE SYNTHESIS OF PLANT GROWTH STIMULATORS BY PHYTOPATHOGENIC BACTERIA AS FACTOR OF PATHOGENICITY
}

\author{
DANKEVYCH, L. ${ }^{1}$ - LEONOVA, N. ${ }^{1}$ - DRAGOVOZ, I. ${ }^{1}-$ PATYKA, V. ${ }^{1}-$ KALINICHENKO, A. ${ }^{2,3}$ \\ WŁODARCZYK, P. ${ }^{2 *}-$ WŁODARCZYK, B. ${ }^{2}$ \\ ${ }^{I}$ Zabolotny Institute of Microbiology and Virology, National Academy of Sciences of Ukraine \\ 154 Acad. Zabolotny str., Kyiv 03143, Ukraine \\ ${ }^{2}$ Department of Process Engineering, Faculty of Natural Sciences and Technology, \\ University of Opole \\ Dmowskiego str. 7-9, 45-365 Opole, Poland \\ ${ }^{3}$ Faculty of Economics and Management, Poltava State Agrarian Academy \\ Skovorody str. 1/3, Poltava 36003, Ukraine \\ *Corresponding author \\ e-mail: pawel.wlodarczyk@uni.opole.pl; phone: +48-77-401-6706 \\ (Received 30 ${ }^{\text {th }}$ Sep 2017; accepted $12^{\text {th }}$ Feb 2018)
}

\begin{abstract}
The environmental changes significantly influence the microorganisms and affect their properties, leading them to take uncharacteristic ecological niches. This study has focused on the ability of phytopathogenic bacteria that belongs to the genera Pseudomonas, Curtobacterium, Ralstonia, Pantoea and Xanthomonas, which are able to cause various diseases of legumes, to produce extracellular phytohormones with stimulatory action in vitro. The qualitative and quantitative composition of extracellular auxins and cytokinins has been determined by spectrodensitometric thin-layer chromatography. This research revealed that the synthesis of plant growth promoting phytohormones that are agents of different plant bacterial disease, play an important role in their pathogenicity and ecological plasticity. In particular, it has been established that the level of auxins synthesis by the studied bacteria, which cause diseases of legumes, correlates directly with their pathogenic properties. Also, a clear connection between the pathways of interaction with plant and the amount and spectrum of synthesized auxins and cytokinins has been revealed.
\end{abstract}

Keywords: phytohormones, phytopathogenic bacteria, pathogens spreading, auxin, cytokinin, bacterial infection

\section{Introduction}

It is known that the environmental changes associated with anthropogenic factor significantly affect both macro and microorganisms. Some researchers have shown that a change in the ecological conditions of microorganisms' existence leads to changes in their properties, allowing them to expand their area of presence. This tendency involves phytopathogenic bacteria. Pathogenic bacteria of polyphagous and monophagous nature expand the number of plant species that they affect. On the other hand, the bacteria, previously considered as opportunistic, increase their level of aggressiveness (Patyka and Pasichnyk, 2014; Zakharova et al., 2015; Patyka et al., 2015). Such changes of phytopathogen's properties occur due to accepting of new mechanisms of virulence, or to improvement of the ways of disease development.

Phytohormones play the regulatory role not only in the key physiological processes of plants, but they are involved also in plant-microbe interactions (Cui et al., 2009; 
Boivin et al., 2016). Five main classes of compounds with phytohormonal activity can be distinguished, such as: auxins, cytokinins, gibberellins, ethylene and abscisic acid. Auxins, cytokinins and gibberellins have a stimulating effect on the key processes of plant ontogenesis, while ethylene and abscisic acid are hormones with inhibiting and anti-stress action. Auxins and cytokinins play an important role in the process of growth and development of plants as well as in their interactions with bacteria, including pathogens. Auxins are derivatives of indole compounds, the most known of which is indole-3-acetic acid (IAA). This compound is produced by plants and microorganisms de novo from tryptophan through many pathways (Woodward and Bartel, 2005; Spaepen et al., 2007). Synthesis of auxins and cytokinins as mechanisms to infect plant tissues is quite common in phytopathogenic bacteria. This process is thoroughly investigated in tumor-inducing species, in particular, Agrobacterium tumefaciens. In these bacteria the genes responsible for synthesis of cytokinins are transferred by bacterial Ti-plasmids, which are integrated into genome of plants (Jameson, 2000). The similar genes were found in cells of other phytopathogenic bacteria (Kakimoto, 2003; Frébort et al., 2011). But, besides the tumor- and gallinducing species, other phytopathogenic bacteria, which cause necrosis, chlorosis, wilts or rots of plants, are also able to synthesize auxins and cytokinins (Jameson, 2000). Information about the role of auxins and cytokinins in plant-pathogen interaction is constantly supplemented with new data (Jin et al., 2003; Navarro et al., 2006; Chen et al., 2007; Ding et al., 2008).

Today, there are following concepts of the influence of auxins on disease development: first, exogenous auxins can weaken stiffness of the plant cell wall - a natural barrier against pathogens (Darley et al., 2001). They stimulate fast growth of plant organs by increasing the size of cells by stretching ("acid growth"). At the initial stage of infection process, pathogens synthesize IAA to stimulate the formation of enzymes of "acid growth" by a plant that induces hydrolysis of polysaccharides of the cell wall. Moreover, disaccharides and monosaccharides, which were released during this process, can serve as an ideal power source for pathogens for their survival and further spread (Lindow and Brandl, 2003). Second, exogenous auxins participate in the work of stomata, ensuring the pathways for invasion of some phytopathogens in plant tissues (Nico-Liu et al., 2006; Gottig et al., 2009). Finally, IAA-signaling can be antagonistic to the SAR-pathway (systemic acquired resistance) of formation of plant resistance to diseases (Chen et al., 2007; Pfeilmeier et al., 2016).

Synthesis of cytokinins as a mechanism for successful invasion into plant tissues is widespread among galls-forming bacteria, which usually have plasmid location of genes responsible for their synthesis. But physiological expedience of these hormones synthesis by non-tumors inducing species of phytopathogenic bacteria is not fully clear (Jameson, 2000).

The complete analysis of synthesis of plants growth promoting phytohormones by pathogenic bacteria, which cause various plant diseases, or differ by virulence properties, is rare. The present study is the first report about quantitative and qualitative analysis of extracellular auxins and cytokinins, synthesized by different species of bacteria pathogenic to legumes in vitro. This study can provide a new perspective on better understanding the compound role that stimulates plants' growth and influences virulence of pathogens, plant infections and development of various diseases types. Also this research will hopefully improve the knowledge about different interactions between pathogen and plant. 


\section{Materials and methods}

The subject of our research is the ability of various types of pathogenic bacteria for legume cultures to synthesize a wide range of extracellular auxins and cytokines. Objects of investigation were strains of phytopathogenic bacteria specified in Table 1. Strain $P$. savastanoi pv. savastanoi $9174^{\mathrm{T}}$, which is able to induce formation of tumors in plants was included in the study as a control.

Table 1. The strains of pathogenic for legumes bacteria used in research

\begin{tabular}{|c|c|}
\hline Species, pathovar, strain & Place isolating, a year, the plant host \\
\hline “Pseudomonas lupini” 8531, 8532, 8533, 8534, 8535 & Ukraine, 1963-1971 years, lupine \\
\hline “Pseudomonas lupini" 17, 6, 22 & Ukraine, 2002-2003 years, lupine \\
\hline "Pseudomonas xanthochlora" 8540 & Ukraine, 1963-1971 years, lupine \\
\hline "Pseudomonas xanthochlora" 3L, 9L & Ukraine, 2006-2007 years, lupine \\
\hline $\begin{array}{c}\text { Pseudomonas syringae pv. syringae } * \text { UCM B-1027 }{ }^{\mathrm{T}} \text { (NCPPB } \\
\text { 281, ICMP } 3023 \text { typical strain) }\end{array}$ & UK, 1950 year, lilac \\
\hline $\begin{array}{c}\text { Pseudomonas savastanoi pv. phaseolicola UCM B-1123 } \\
\text { (**NCPPB 52, ***ICMP } 2740 \text { pathotype strain) }\end{array}$ & Canada $-* * * *$, beans \\
\hline $\begin{array}{c}\text { Pseudomonas syringae pv. pisi } 9177^{\mathrm{T}} \text { (ICMP 2452, NCPPB } \\
2585 \text { pathotype strain) }\end{array}$ & New Zealand, 1969 year, peas \\
\hline $\begin{array}{c}\text { Pseudomonas savastanoi pv. savastanoi } 9174^{\mathrm{T}}(\mathrm{NCPPB} 639, \\
\text { ICMP } 4352 \text { pathotype strain) }\end{array}$ & Yugoslavia, 1959 year, oil \\
\hline $\begin{array}{c}\text { Pseudomonas marginalis pv. marginalis } 9175^{\mathrm{T}} \text { (NCPPB 667, } \\
\text { ICMP } 3553 \text { typical strain) }\end{array}$ & Belgium, chicory \\
\hline Pseudomonas savastanoe pv. glycinea 8571 (NCPPB 1139) & Zimbabwe, soybeans \\
\hline Curtobacterium flacumfaciens pv. flacumfaciens 6564 & Ukraine, 1952 year, beans \\
\hline $\begin{array}{l}\text { Ralstonia solanacearum UCM B-1109 }{ }^{\mathrm{T}} \text { (NCPPB } 325, \text { ICMP } \\
5712 \text { typical strain) }\end{array}$ & USA, 1953 year, tomato \\
\hline Pantoea agglomerans 8490 & Romania, 1970 year, oats \\
\hline Pseudomonas syringae pv. tabaci 225 & Ukraine, 1946 year, tobacco \\
\hline Xanthomonas axonopodis pv. glycines 8609 & Ukraine, 1960 year, soybean \\
\hline
\end{tabular}

Notes: 1.*UCM - Ukrainian Collection of Microorganisms; 2.**NCPPB National Collection of Plant Pathogenic Bacteria, UK; 3.***ICMP - International Collection of Microorganisms from Plants, New Zealand; 4.**** - data available

Phytopathogenic bacteria of the genera: Pseudomonas, Curtobacterium, Ralstonia, Pantoea were cultured in the mineral Omelyansky medium $\left(\mathrm{H}_{2} \mathrm{O}\right.$ distilled - 11.; $\mathrm{K}_{2} \mathrm{HPO}_{4}-1.0 \mathrm{~g} ;\left(\mathrm{NH}_{4}\right)_{2} \mathrm{HPO}_{4}-1.0 \mathrm{~g} ; \mathrm{MgSO}_{4}-0.5 \mathrm{~g} ; \mathrm{CaCl}_{2}-0.1 \mathrm{~g} ; \mathrm{NaCl}$ and $\mathrm{FeSO}_{4}-$ trace amounts) for $24-48 \mathrm{~h}$ in $750 \mathrm{ml}$ flasks on a shaker $\left(220 \mathrm{rev} \min ^{-1}\right)$ at $26-28{ }^{\circ} \mathrm{C}$. Bacteria of the genus Xanthomonas were cultured in similar conditions in the synthetic Lich (Lili) medium $\left(\mathrm{H}_{2} \mathrm{O}\right.$ distilled - $1.0 \mathrm{l}$; casein - $2.0 \mathrm{~g}$; fumaric acid - $1.3 \mathrm{~g} ; \mathrm{K}_{2} \mathrm{HPO}_{4}$ $-1.0 \mathrm{~g} ; \mathrm{MgSO}_{4} \cdot 7 \mathrm{H}_{2} \mathrm{O}-0.5 \mathrm{~g} ; \mathrm{Na}_{2} \mathrm{CO}_{3}-1.1 \mathrm{~g} ; \mathrm{Fe}_{2}\left(\mathrm{SO}_{4}\right)_{3}-0.2 \mathrm{mg} ; \mathrm{ZnSO}_{4}-0.2 \mathrm{mg}$; $\mathrm{MgSO}_{4}-0.1 \mathrm{mg}$; glucose $-15 \mathrm{~g}$ ). To determine the specrum of exogenous auxins the culture medium was added with $0.1 \%$ tryptophan.

In order to separate the biomass, the culture fluids of bacteria were centrifuged for $20 \mathrm{~min}$ at $9000 \mathrm{rev} \mathrm{min}^{-1}$ and at $4{ }^{\circ} \mathrm{C}$. The cells of bacteria were washed three times. The supernatants were used for further investigation to extract phytohormonal 
compounds. The sediment of cells was suspended in distilled water and then dried at $103-105{ }^{\circ} \mathrm{C}$ in a desiccator, until constant weight. The amount of absolutely dry biomass (ADB) of microorganisms was determined gravimetrically. Determination of qualitative and quantitative composition of phytohormones in the culture fluids of phytopathogenic bacteria was performed by spectrodensitometric thin-layer chromatography (Pant and Agrawal, 2014; Leonova, 2015). Extracellular auxins and cytokinins were isolated from the supernatants of phytopathogenic bacteria by extraction of phytohormones with acetic acid ethyl ether at $\mathrm{pH} 3.0$ and with n-butanol at $\mathrm{pH}$ 8.0. The obtained extracts were evaporated under vacuum at $40-45{ }^{\circ} \mathrm{C}$. The dry sediment was dissolved in ethanol. Ethanol extracts of the supernatants of the studied bacteria were used for accumulative thin-layer chromatography. Quantitative determination of auxins and cytokinins was performed by using a Sorbfil scanning spectrodensitometer. In the research the synthetic standards of phytohormones were used, produced by companies Sigma-Aldrich and Acros Organic.

All experiments were performed in 6 iterations. The results obtained were processed statistically using computer program Excel from licensed Microsoft Office 2010. In the table and the figures the average values and standard errors $(M \pm m)$ are presented. Values of $P<0.05$ were considered to be significant.

\section{Results and discussion}

It has been shown that legumes pathogenic bacteria are able to produce a wide range of both auxins and cytokinins (Fig. 1).
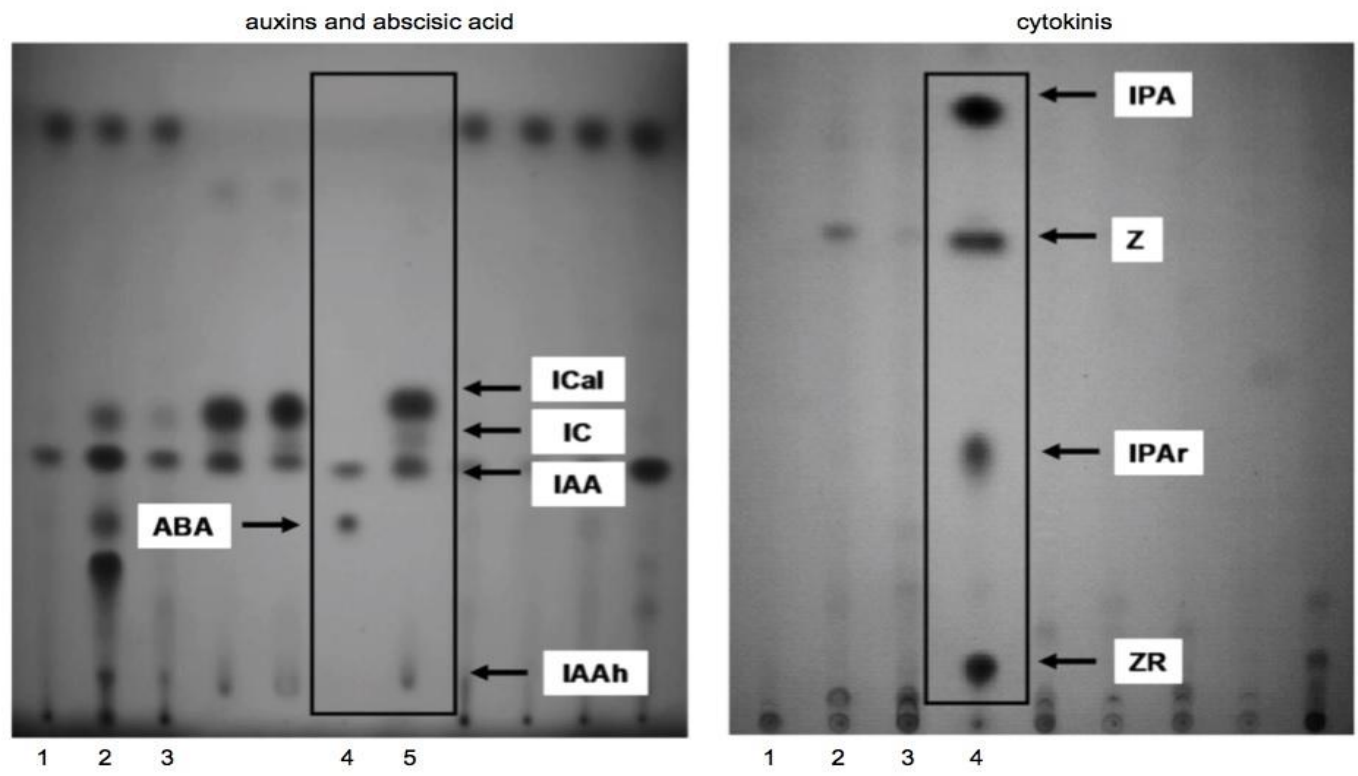

$1,2,3$ - samples of pathogenic bacteria strains; 4,5 - synthetic phytohormones standards

Figure 1. Detection of auxins, abscisic acid and cytokinins by TLC produced by phytopathogenic bacteria in thin layers of silicon oxide and aluminum oxide (Merck, $\left.U V_{254}\right)$ : IAA - Indole-3-acetic acid; ICal-Indole-3-carboxaldehyde; IC - Indole-3-carbinol; ABA abscisic acid; IAAh - Indole-3-acetic hydrazide; IPA - $N^{6}-(2$-Isopentenyl)adenine; $Z$ - zeatin; $I P A r-N^{6}$-(2-Isopentenyl)adenosine; ZR - trans-Zeatin-riboside 
The results show that the level of auxin synthesis by legumes pathogenic bacteria correlates directly with their pathogenic properties. Thus, the pathogens, which can affect a wide range of plants (polyphagous) $-P$. syringae pv. syringae $\mathrm{B}-1027^{\mathrm{T}}$, P. marginalis pv. marginalis $9175^{\mathrm{T}}$ and $P$. savastanoi pv. savastanoi $9174^{\mathrm{T}}$ synthesize higher levels of auxins (from 1987.91 to $1362.46 \mu \mathrm{g} \mathrm{g}^{-1}$ ADB) compared with the phytopathogenic bacteria that cause disease in only one host plant (monophagous) P. savastanoi pv. phaseolicola $\mathrm{B}-1123^{\mathrm{T}}$, P. syringae pv. pisi $9177^{\mathrm{T}}$ (from 825.87 to $1267.5 \mu \mathrm{g} \mathrm{g}^{-1}$ ADB) (Table 2).

Table 2. Analysis of extracellular auxins and cytokinins synthesis by pathogenic for legumes bacterial strains of the genus Pseudomonas with their pathogenic properties

\begin{tabular}{|c|c|c|c|}
\hline \multirow[t]{2}{*}{ Strains } & \multicolumn{2}{|c|}{$\begin{array}{c}\text { Amount of phytohormones, } \\
\mu g / g \text { of absolutely dry } \\
\text { biomass (ADB) }\end{array}$} & \multirow[t]{2}{*}{ Pathogenic properties } \\
\hline & Auxins & Cytokinins & \\
\hline $\begin{array}{l}\text { P. syringae pv. phaseolicola UCM B- } \\
1123^{\mathrm{T}}\end{array}$ & 1267.5 & 66.13 & $\begin{array}{c}\text { Monophagous, bean angular } \\
\text { leaf spot }\end{array}$ \\
\hline P. syringae pv. pisi $9177^{\mathrm{T}}$ & 825.87 & 92.03 & $\begin{array}{c}\text { Monophagous, pea bacterial } \\
\text { blight }\end{array}$ \\
\hline P. syringae pv. syringae UCM B- $1027^{\mathrm{T}}$ & 1987.91 & 76.4 & $\begin{array}{c}\text { Polyphagous, cause different } \\
\text { types of plant's disease } \\
\text { belongs to more than } 50 \\
\text { species }\end{array}$ \\
\hline P. marginalis pv. marginalis $9175^{\mathrm{T}}$ & 1362.46 & 170.90 & $\begin{array}{c}\text { Polyphagous, cause disease of } \\
\text { many plants species }\end{array}$ \\
\hline $\begin{array}{l}\text { P. savastanoi pv. savastanoi } 9174^{\mathrm{T}} \\
\text { (1 day cultivation) }\end{array}$ & 344.67 & 331.97 & $\begin{array}{c}\text { Monophagous, causes } \\
\text { tumours of plants which } \\
\text { belongs to family Oleaceae }\end{array}$ \\
\hline
\end{tabular}

Furthermore, synthesis of auxins by tumor-inducing strain $P$. savastanoi pv. savastanoi $9174^{\mathrm{T}}$ occurs gradually, respectively: $344.67 \mu \mathrm{g} \mathrm{g}^{-1} \mathrm{ADB}$ - the first day of culturing and $1893.24 \mu \mathrm{g} \mathrm{g}^{-1}$ ADB - the second day of cultivation. This probably confirms the fact that the gradual synthesis of auxins causes stage-by-stage changes in hormonal regulation of plants, whch ultimately leads to a gradual damage of plant tissue structure (Biovin et al., 2016; Jameson, 2000). Instead, already on the first day of cultivation, P. syringae pv. syringae $\mathrm{B}-1027^{\mathrm{T}}$, P. marginalis pv. marginalis $9175^{\mathrm{T}}$, significant amounts of auxins were synthesized, which indicates the possibility of using this indole compounds as the key virulence factors that quickly unbalance the hormonal regulation system of plants (Biovin et al., 2016; Jameson, 2000). Also, it should be noted that both polyphagous and monophagous differ in the spectrum of synthesized auxins (Fig. 2).

The representatives of pathovars of phaseolicola, pisi, syringae, included in the research, synthesize medium amounts of both IAA and indole-3-carboxylic acids, and indole-3-acetic acid hydrazide (from 41.5-58.3 to 39.71-53.1\% of the total amount of auxins). Strain $P$. savastanoi pv. savastanoi $9174^{\mathrm{T}}$ synthesizes almost equal numbers of both IAA and indole-3-carboxylic acids, and indole-3-carboxy-aldehyde (56.05 and $42.5 \%$ of the total amount of auxins). However almost $100 \%$ of auxins, synthesized by strain P. marginalis pv. marginalis $9175^{\mathrm{T}}$, accounted for IAA and indole-3-carboxylic acid (Fig. 2). No dependency was found between the number and range of synthesized 
cytokinins and the pathogenic properties of polyphagous $P$. syringae pv. syringae B$1027^{\mathrm{T}}, P$. marginalis pv. marginalis $9175^{\mathrm{T}}$, as well as monophagous $P$. syringae pv. phaseolicola $\mathrm{B}-1123^{\mathrm{T}}$, P. syringae pv. pisi $9177^{\mathrm{T}}$ (Fig. 3).

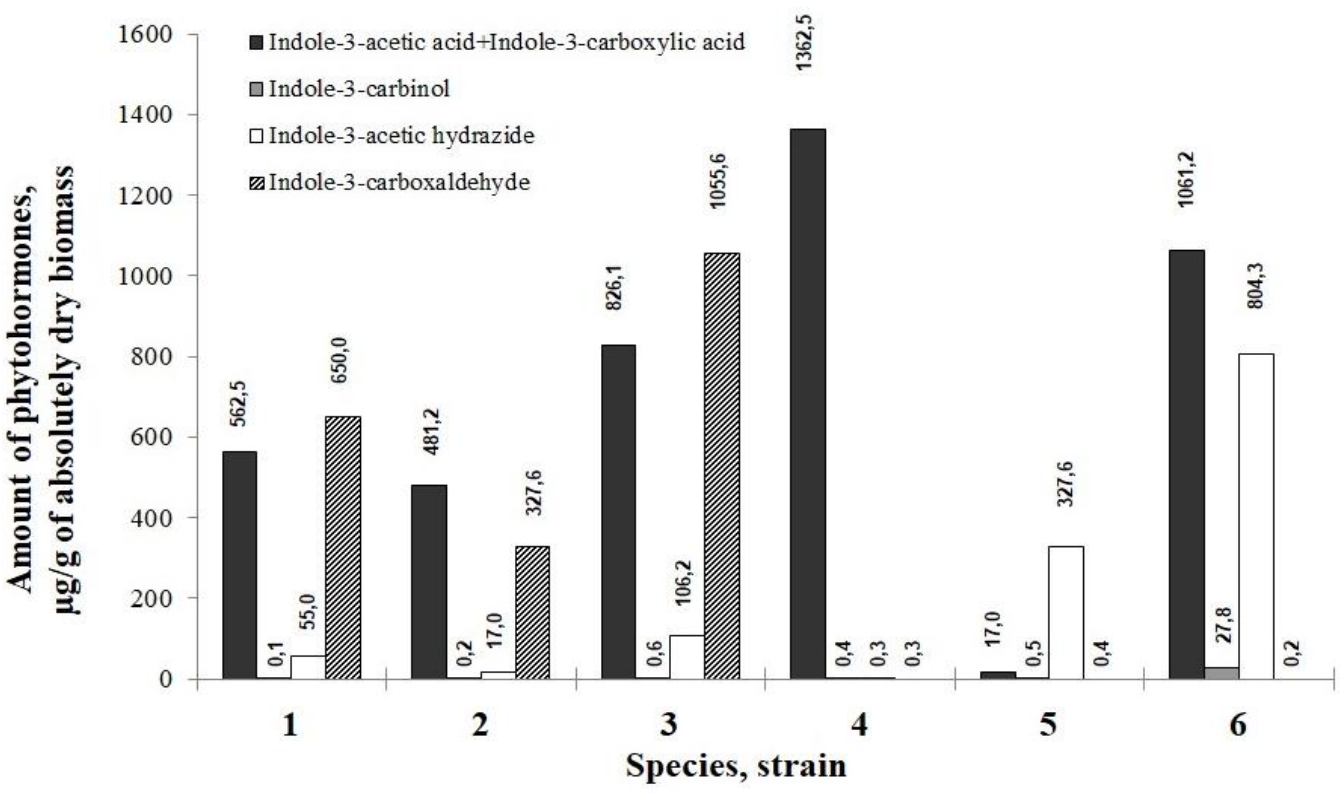

Figure 2. Synthesis of extracellular auxins by pathogenic for legume representatives of genus Pseudomonas: $1-P$. syringae pv. phaseolicola UCM B-1123T, $2-P$. syringae pv. pisi $9177^{T}, 3$ - P. syringae pv. syringae UCM B-1027, $4-P$. marginalis pv. marginalis $9175^{T}, 5-P$. savastanoi pv. savastanoi $9174^{T}$ (1 day cultivation), $6-P$. savastanoi pv. savastanoi $9174^{T}$ ( 2 days cultivation). Here and after: $M \pm m, n=6 ; P<0.05$ vs. control

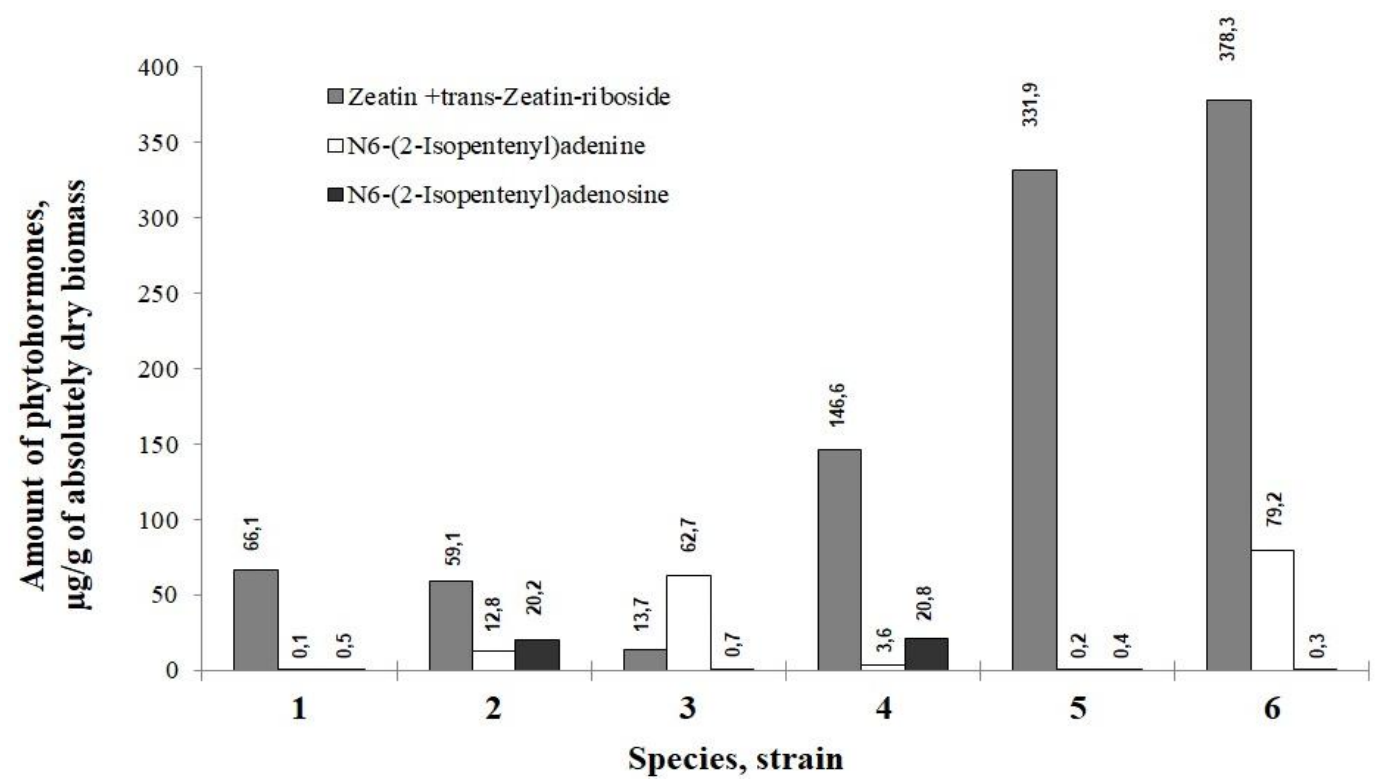

Figure 3. Synthesis of extracellular cytokinins by pathogenic for legume representatives of genus Pseudomonas: $1-P$. syringae pv. phaseolicola UCM B-1123 ${ }^{T}, 2-P$. syringae pv. pisi $9177^{T}, 3-P$. syringae pv. syringae UCM $B-1027^{T}, 4-P$. marginalis pv. marginalis $9175^{T}, 5-$ P. savastanoi pv. savastanoi $9174^{T}$ (1 day cultivation), 6 - P. savastanoi pv. savastanoi $9174^{T}(2$ days cultivation) 
The highest levels of cytokinin synthesis were observed in tumor-inducing strain $P$. savastanoi pv. savastanoi $9174^{\mathrm{T}}$, both on the first and on the second day of culturing (331.97-457.51 $\left.\mathrm{g} \mathrm{g} \mathrm{g}^{-1} \mathrm{ADB}\right)$. Also, it should be noted that this strain is able to synthesize the largest amount of such forms of cytokinins as zeatin and zeatin-riboside (Fig. 3).

During the research, on the example of two pathogens of bacterial diseases of lupine: "Pseudomonas lupini" (brown bacterial spot) and "Pseudomonas xanthochlora" (wet watery rot), a direct correlation between the level of aggressiveness of a strain on plants and the amount of synthesized auxins has been revealed (Table 3).

Table 3. Comparative characteristics of the amounts of extracellular auxins and cytokinins what synthesized by not valid taxa of pathogenic bacteria of the genus Pseudomonas with their level of aggressiveness on the zoned lupine's varieties

\begin{tabular}{|c|c|c|c|}
\hline \multirow{2}{*}{ Strains } & \multicolumn{2}{|c|}{$\begin{array}{l}\text { Amount of phytohormones, } \mu \mathrm{g} / \mathrm{g} \text { of } \\
\text { absolutely dry biomass (ADB) }\end{array}$} & \multirow{2}{*}{$\begin{array}{c}\text { Intermediate } \\
\text { aggressive strains } \\
\text { on host plants, } \\
\text { scores }\end{array}$} \\
\hline & Auxins & Cytokinins & \\
\hline P. syringae ("P. lupine") 8531 & 1554.82 & Not determined & $6.6 \pm 0.23$ \\
\hline P. syringae (“P. lupine”) 8532 & 586.36 & 94.52 & $5.6 \pm 0.10$ \\
\hline P. syringae ("P. lupine”) 8533 & 562.83 & \multirow{2}{*}{ Not determined } & $4.4 \pm 0.19$ \\
\hline P. syringae (“P. lupine”) 8534 & 914.05 & & $4.4 \pm 0.12$ \\
\hline P. syringae ("P. lupine”) 8535 & 1168.08 & & $4.5 \pm 0.25$ \\
\hline P. syringae ("P. lupine") 6 & 2124.89 & 102.23 & $8.5 \pm 0.40$ \\
\hline P. syringae ("P. lupine”) 17 & 2074.77 & Not determined & $8.2 \pm 0.50$ \\
\hline P. syringae ("P. lupine") 22 & 98.46 & 4.56 & $2.0 \pm 0.10$ \\
\hline "P. xanthochora" 8540 & 1207.68 & 27.66 & $7.7 \pm 0.25$ \\
\hline "P. xanthochora" 3L & 1201.22 & 23.26 & $7.0 \pm 0.1$ \\
\hline "P. xanthochora" 9L & 391.99 & tr. & $2.0 \pm 0.5$ \\
\hline
\end{tabular}

Note: "tr." - found trace amounts

In particular, low aggressive strains of Pseudomonas xanthochlora produced amounts of auxins 3 times or more smaller than the highly aggressive strains. A similar regularity can be observed for Pseudomonas lupini. Thus, low aggressive strain "Pseudomonas lupini" 22 synthesizes the amount of auxins 21 or more times less than highly aggressive strains Pseudomonas lupini 6 and 17. However, in the medium aggressive and low aggressive collection strains of Pseudomonas lupini, this correlation between the level of aggressiveness and the total amount of synthesized auxins is not observed so clearly (Table 3). No direct connection between the range of indole compounds and aggressiveness of the strains has been found. Also, it should be noted that more than $90 \%$ of all auxins synthesized by low aggressive strain Pseudomonas xanthochlora 9L accounted for IAA, which re-affirms the primary role of the compound in initiation and development of microbe-plant interaction (Fig. 4). In addition, it was established that there is a correlation between the level of aggressiveness of a strain and the amount of synthesized cytokinins. Thus, the 
smallest amounts of these compounds are synthesized by low aggressive strains Pseudomonas xanthochlora 9L and Pseudomonas lupini 22 (from trace amounts to $\left.4.56 \mu \mathrm{g} \mathrm{g}^{-1} \mathrm{ADB}\right)$. Also, it should be noted that in all of the investigated strains the level of zeatin and its transport form zeatin-riboside makes the highest percentage of the pool of synthesized cytokinins (Fig. 5).

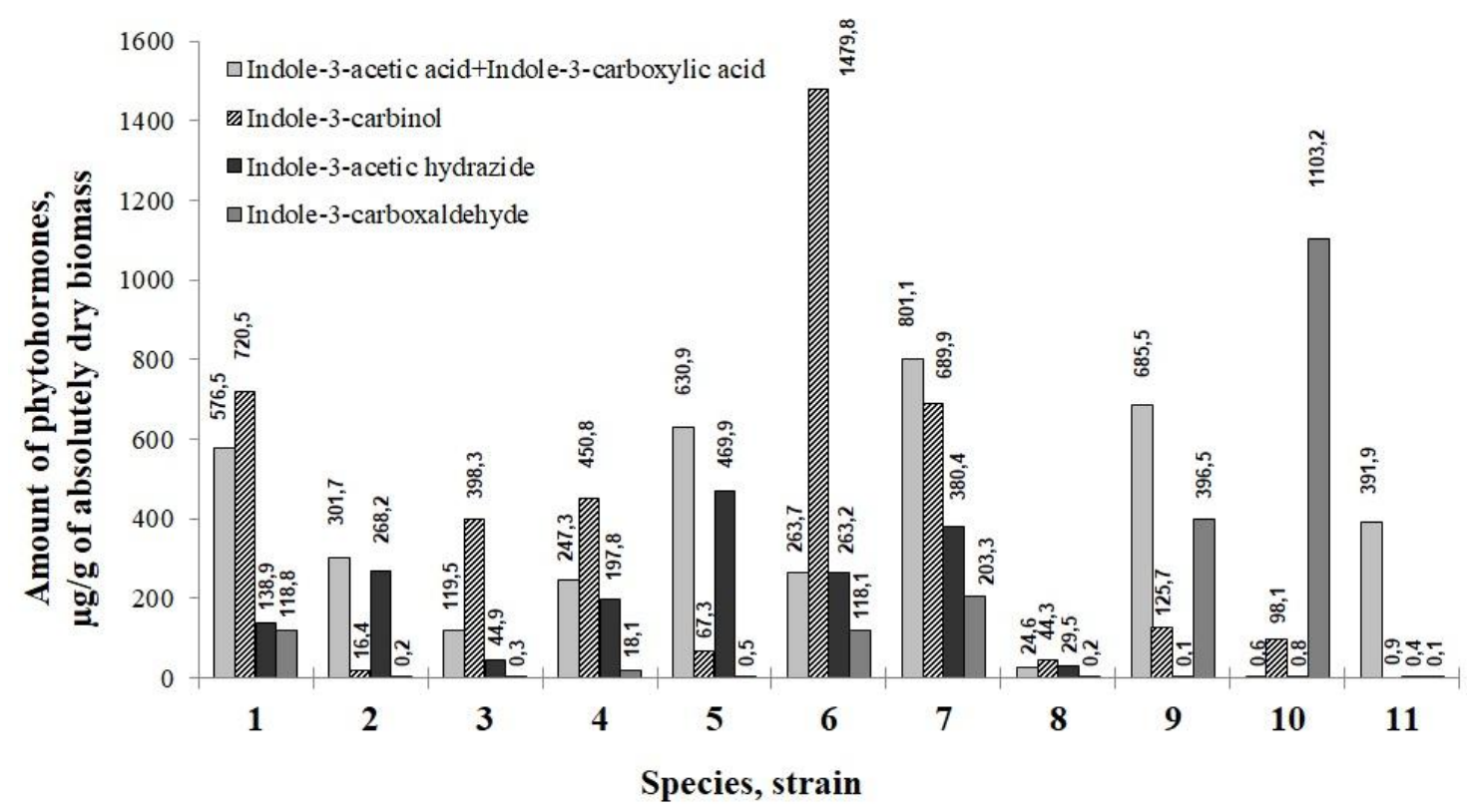

Figure 4. Synthesis of extracellular auxins by pathogenic for lupine representatives of genus Pseudomonas: (A) - 1, 2, 3, 4, 5, 6, 7, 8 - "P. lupini" 8531, 8532, 8533, 8534, 8535, 6, 17, 22 and 9, 10, $11-$ "P. xanthochora" 8540, 3L, 9L

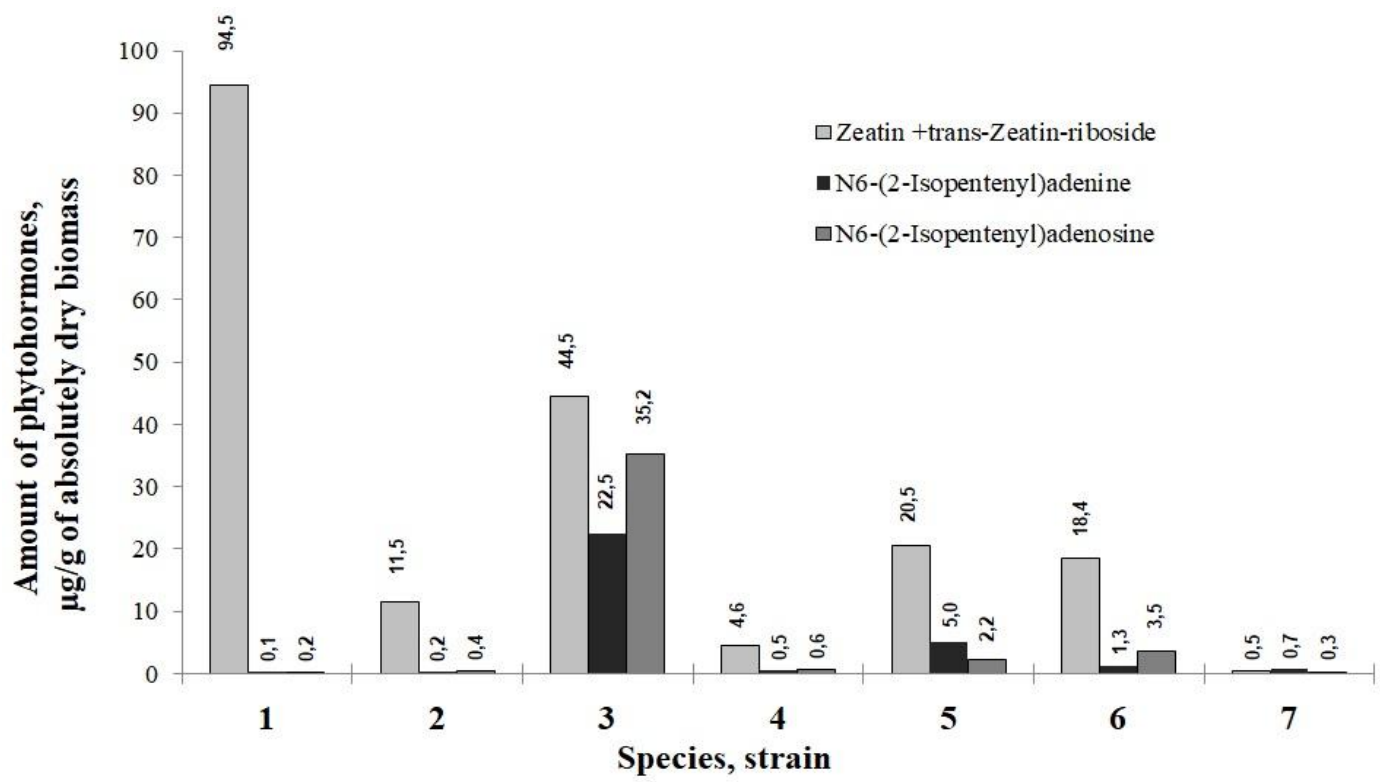

Figure 5. Synthesis of extracellular cytokinin by pathogenic for lupine representatives of genus Pseudomonas: 1, 2, 3, 4- "P. lupini" 8532, 8535, 6, 22 and 5, 6, 7 - "P. xanthochora" 8540, $3 L, 9 L$ 
We have studied an ability to synthesize extracellular auxins and cytokinins by pathogens of various types of bacterial diseases of soybean. It has been established that an amount of synthesized auxins and their range depends on the pathogen's properties and the features of its interaction with a plant. Polyphagous $R$. solanacearum UCM B-1109 ${ }^{\mathrm{T}}$, P. syringae pv. tabaci 225 , C. flaccumfaciens $\mathrm{pv}$. flaccumfaciens 6564 produce large amounts of auxins (from 1512.29 up to $948.8 \mu \mathrm{g} \cdot \mathrm{g}^{-}$ ${ }^{1}$ ADB) (Table 4) Monophagous X. axonopodis pv. glycines 8609 and P. savastanoi pv. glycinea 8571 synthesize more smaller amounts of auxins (from 445.09 to 147.38 $\mu \mathrm{g} \cdot \mathrm{g}^{-1}$ ADB). The highest levels of synthesis of these indole compounds were observed in strains $R$. solanacearum UCM B-1109 ${ }^{\mathrm{T}}\left(1256.81 \mu \mathrm{g} \cdot \mathrm{g}^{-1} \mathrm{ADB}\right), P$. agglomerans $8490\left(1327.0 \mu \mathrm{g} \cdot \mathrm{g}^{-1} \mathrm{ADB}\right)$ and C. flaccumfaciens pv. flaccumfaciens $6564\left(1512.29 \mu \mathrm{g} \cdot \mathrm{g}^{-1} \mathrm{ADB}\right)$.

Table 4. Comparative analysis of extracellular auxins and cytokinins synthesis by agents of soybean's bacterial diseases with their pathogenic properties

\begin{tabular}{|c|c|c|c|}
\hline \multirow[t]{2}{*}{ Strains } & \multicolumn{2}{|c|}{$\begin{array}{c}\text { Amount of phytohormones, } \\
\mu \mathrm{g} / \mathrm{g} \text { of absolutely dry biomass } \\
\text { (ADB) }\end{array}$} & \multirow[t]{2}{*}{ Pathogenic properties } \\
\hline & Auxins & Cytokinins & \\
\hline $\begin{array}{l}\text { C. flacumfaciens pv. flacumfaciens } \\
\qquad 6564\end{array}$ & 573.29 & 50.81 & $\begin{array}{l}\text { Polyphagous, bacterial tan spot } \\
\text { of soybean and bacterial wilt of } \\
\text { bean }\end{array}$ \\
\hline R. solanacearum UCM B- $1109^{\mathrm{T}}$ & 1256.81 & 222.1 & $\begin{array}{l}\text { Polyphagous, bacterial wilting } \\
\text { of many plants }\end{array}$ \\
\hline P. agglomerans 8490 & 1327.0 & 323.51 & $\begin{array}{c}\text { Polyphagous, disease like } \\
\text { bacterial stem stripe and wet } \\
\text { spottiness a of various crops }\end{array}$ \\
\hline P. syringae pv. tabaci 225 & 510.18 & 194.00 & $\begin{array}{c}\text { Polyphagous, wildfire of } \\
\text { soybean and tobacco }\end{array}$ \\
\hline P. savastanoi pv. glycinea 8571 & 445.09 & 75.30 & $\begin{array}{c}\text { Monophagous, angual leaf spot } \\
\text { of soybean }\end{array}$ \\
\hline X. axonopodis pv. glycines 8609 & 586.0 & 102.27 & $\begin{array}{l}\text { Monophagous, soybean } \\
\text { bacterial pustule }\end{array}$ \\
\hline
\end{tabular}

Pathogens of bacterial diseases of soybean differ not only by quantitative, but also by the spectrum of synthesized auxins. In particular, the highest levels of IAA and indole3-carboxylic acid synthesis were found in both monophagous $X$. axonopodis $\mathrm{pv}$. glycines 8609 (near $100 \%$ of the total amount of auxins) and polyphagous $C$. flaccumfaciens pv. flaccumfaciens (over 90\%). Also, it should be noted that high level of production of both IAA and indole-3-carboxylic acid was found in P. agglomerans 8490 (over 50\%). However, low levels of synthesis of IAA and indole-3-carboxylic acid were observed in both monophagous $P$. savastanoi pv. glycinea 8571 (about 48\%) and polyphagous $P$. syringae pv. tabaci 225 (about 28\%) and $R$. solanacearum UCM B$1109^{\mathrm{T}}$ (over 29\%) (Fig. 6).

In the investigation of cytokinin activity of strains - pathogens of soybean bacterial diseases, we have shown that the high level of synthesis of cytokinins is observed in polyphagous $R$. solanacearum UCM B- $1109^{\mathrm{T}}\left(222.1 \mu \mathrm{g} \cdot \mathrm{g}^{-1} \mathrm{ADB}\right)$ and $P$. agglomerans 8490 (323.51 $\mu \mathrm{g} \cdot \mathrm{g}^{-1}$ ADB) (Table 4). Also, it should be noted that both $R$. solanacearum 
UCM B-1109 ${ }^{\mathrm{T}}$ and $P$. agglomerans 8490 synthesize rather large amounts of a transport form of zeatin - zeatin-riboside $(65.17-32.46 \%$ of the total amount of cytokinins respectively) (Fig. 6). Instead, the other studied strains have lower levels of synthesis of exogenous cytokinins (from 194.00 to $50.81 \mu \mathrm{g} \cdot \mathrm{g}^{-1} \mathrm{ADB}$ ) compared with the abovementioned strains. In addition, $P$. syringae pv. tabaci 225, C. flaccumfaciens pv. flaccumfaciens 6564 and $X$. axonopodis pv. glycines 8609 are also able to synthesize significant amounts of zeatin-riboside (from 22.04 to 51.14\%) (Fig. 7).

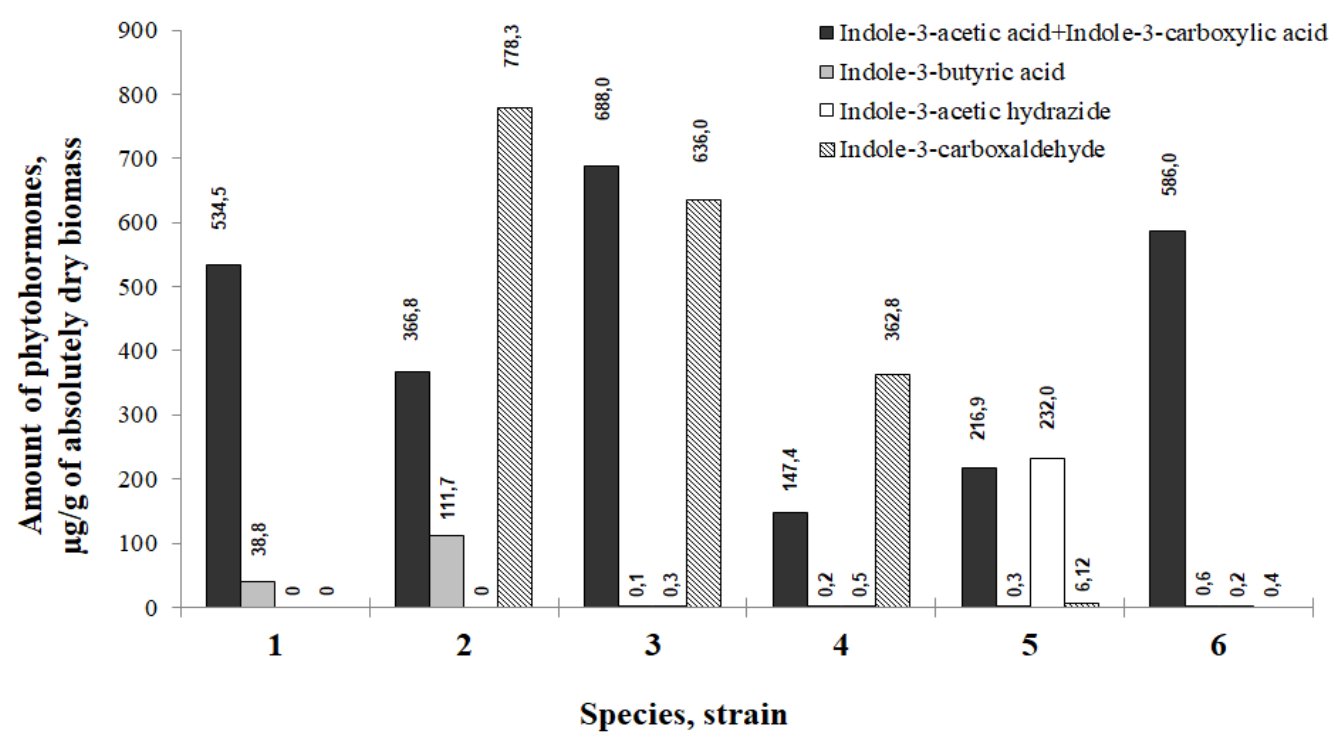

Figure 6. Synthesis of extracellular auxins by pathogenic for soybean bacteria: 1 -

Curtobacterium flacumfaciens pv. flacumfaciens 6564, 2 - Ralstonia solanacearum UCM B$1109^{T}, 3$ - Pantoea agglomerans 8490, 4- Pseudomonas syringae pv. tabaci 225, 5 -

Pseudomonas savastanoi pv. glycinea 8571, 6-Xanthomonas axonopodis pv. glycines 8609

\section{Discussion}

It has been shown that the polyphagous and strains with a high level of aggressiveness synthesize much higher levels of auxins, compared with the monophagous and strains with a low level of aggressiveness. This fact does not contradict the literature data. In particular, certain researchers had shown that spontaneous mutant Pseudomonas fluorescens HP72 synthesizes only a small amount of IAA and has a low ability to colonize roots of bent grass (Biovin et al., 2016). The strain of Erwinia chrysanthemi, which is mutant by the synthesis of IAA, has very low levels of synthesis of pectate lyase that worsens local maceration of plant's tissues (Yang et al., 2007).

It has been established that an amount of synthesized auxins and their range depends on the biology of a pathogen and the features of its interaction with a plant. In particular, strains $P$. syringae pv. syringae $\mathrm{B}-1027^{\mathrm{T}}$, $P$. savastanoi pv. phaseolicola $\mathrm{B}-$ $1123^{\mathrm{T}}$, P. syringae pv. pisi $9177^{\mathrm{T}}$, P. savastanoi pv. glycinea 8571 , P. syringae pv. tabaci 225 and $R$. solanacearum $\mathrm{B} 1109^{\mathrm{T}}$ synthesize low and medium amounts of both IAA and indole-3-carboxylic acids. It is known that representatives of pathovars of glycinea, phaseolicola, pisi, syringae, tabaci are able to synthesize specific pathogenicity factors, in particular, toxins, synthesis of which may correlate with production of IAA. Thus, it was shown that strains of $P$. syringae pv. syringae, mutant 
relating to IAA synthesis, significantly reduced production of syringomycin and, consequently, the virulence (Hwang et al., 2005). In addition, researchers have shown that synthesis of IAA by $R$. solanacearum and P. syringae is directly related to HRPgene-encoded type III secretion system (Type III secretion systems (T3SSs)), which is directly transcribed into effector proteins (hairpins) in the host plant cells and it is the key to development of infection process and disease symptoms (Jin et al., 2003; Fouts et al., 2002). Probably, rather high level of synthesis of auxins, in particular, IAA, by $P$. agglomerans 8490 is related to the ability of this species to colonize all components of phyllosphere, because the interaction with a plant is a characteristic feature of the biology of this species. Also, it is known that P. agglomerans are able to synthesize IAA in three ways (Spaepen et al., 2007). It appears that the presented above facts fully explain the research results. The auxins for these strains play a role of signaling molecules that start a cascade of other pathogenicity reactions rather than the role of key factors of virulence, probably. However, in strains P. marginalis pv. marginalis $9175^{\mathrm{T}}$, $X$. axonopodis pv. glycines 8609 and C. flaccumfaciens pv. flaccumfaciens 6564 synthesis of the mentioned above indole compounds plays the crucial role in mechanisms of their interaction with a plant (the increased permeability of the plant cell wall, disturbance in stomata work, inhibition of responses of plant protection, etc.), because, according to the literature, information about them having specific pathogenicity factors and their relationship to synthesis of auxins is almost absent.

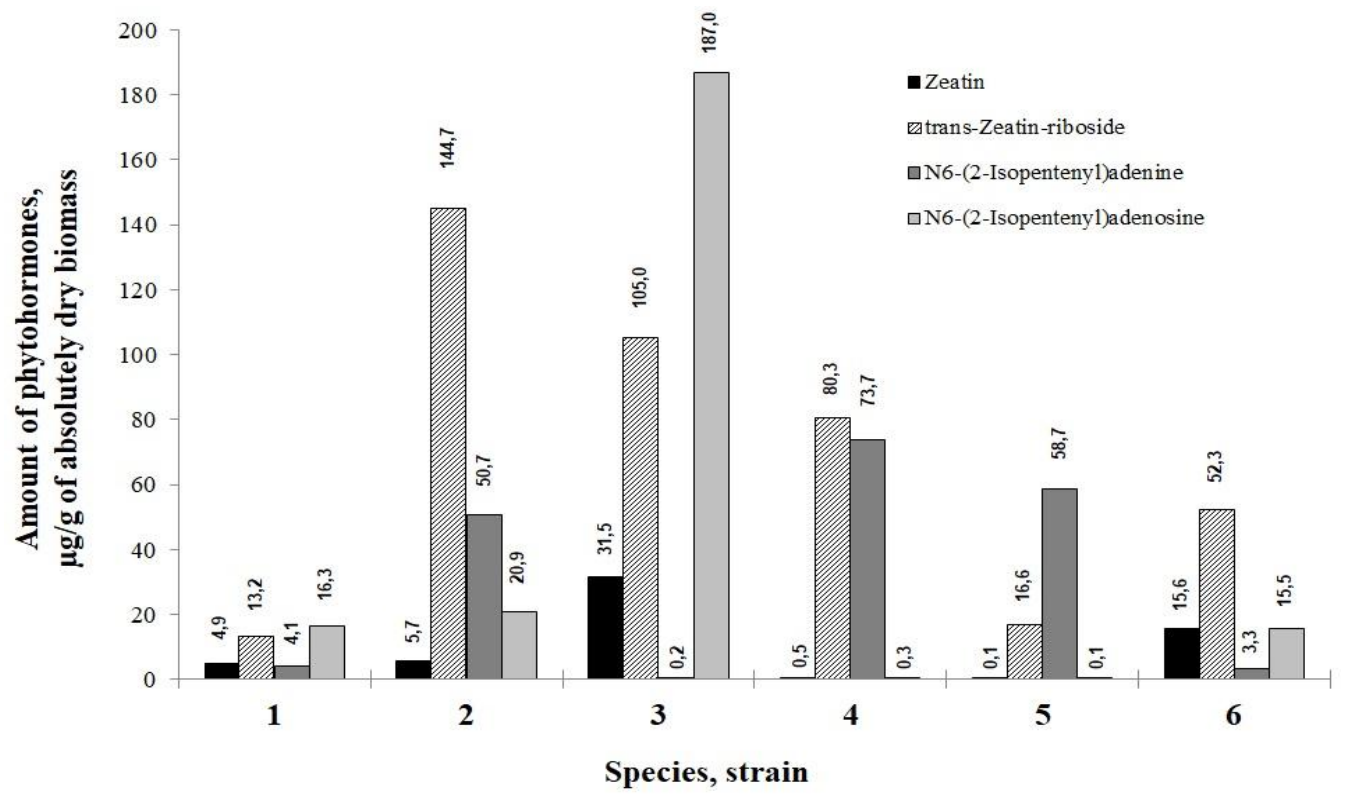

Figure 7. Synthesis of extracellular cytokinins by pathogenic for soybean bacteria: 1 Curtobacterium flacumfaciens pv. flacumfaciens 6564, 2 - Ralstonia solanacearum UCM B$1109^{T}, 3$ - Pantoea agglomerans 8490, 4-Pseudomonas syringae pv. tabaci 225, 5 -

Pseudomonas savastanoi pv. glycinea 8571, 6-Xanthomonas axonopodis pv. glycines 8609

According to the literature, bacteria synthesize cytokinins, using them primarily as a chemical signal to interact with plant or as a mechanism for successful invasion into plant tissues (Giron et al., 2013). Using the example of $R$. solanacearum, a connection between auxin and cytokinin signaling and plant roots susceptibility to this pathogen has been revealed (Kakimoto, 2003; Giron et al., 2013). The high level of synthesis of 
cytokinins by $P$. agglomerans 8490 is likely to be connected with peculiarities of the biology of this species.. Moreover, as in the case of tumor-inducing species, in representatives of species $P$. agglomerans and $R$. solanacearum the genes trm/tzs, responsible for synthesis of auxins and cytokinins, are localized in plasmids. Therefore, the number of their copies is much larger, compared to the species with nucleoid location of the similar genes (Kakimoto, 2003).

\section{Conclusion}

It has been determined that the level of synthesized auxins produced by the studied bacteria correlates directly with their pathogenic properties. A connection between the ways of plants' infection and the amount and spectrum of synthesized auxins and cytokinins has been estabilshed. In particular, certain types of phytopathogenic bacteria, in which formation of specific pathogenicity factors (toxins, enzymes) is connected to production of auxins, synthesize low and medium amounts of indole-3-acetic acid and indole-3-carboxylic acid. For these pathogens, these compounds probably act as signaling molecules, triggering reactions of other mechanisms of pathogenesis. However, the other species, for which there is not any known connection of synthesis of specific pathogenicity factors with auxin signaling, are able to synthesize significant amounts of mentioned above indole compounds, which probably play a crucial role in their interaction with the plant.

Our investigation of quality and quantity phytohormones compositions synthesized by different pathogenic for plants bacteria will improve the understanding of pathogenplant interactions and, thus, will create preconditions for developing strategies to prevent the pathogens spreading.

\section{REFERENCES}

[1] Boivin, S., Fonouni-Farde, C., Frugie, F. (2016): How auxin and cytokinin phytohormones modulate root microbe interactions. - Front. Plant Sci. 7: 1-12.

[2] Chen, Z., Agnew, J. L., Cohen, J. D., He, P., Shan, L., Sheen, J., Kunkel, B. N. (2007): Pseudomonas syringae type III effector AvrRpt2 alters Arabidopsis thaliana auxin physiology. - Proceedings of the National Academy of Sciences of the United States of America 104(50): 20131-20136.

[3] Cui, H., Xiang, T., Zhou, J-M. (2009): Plant immunity: a lesson from pathogenic bacterial effector proteins. - Cellular Microbiology 11(10): 1453-1461.

[4] Darley, C. P., Forrester, A. M., McQueen-Mason, S. J. (2001): The molecular basis of plant cell wall extension. - Plant Mol. Biol. 47: 179-195.

[5] Ding, X., Cao, Y., Huang, L., Zhao, J., Xu, C., Li, X., Wang, Sh. (2008): Activation of the indole-3-acetic acid-amido synthetase GH3-8 suppresses expansin expression and promotes salicylate- and jasmonate-independent basal immunity in rice. - Plant Cell 20(1): 228-240.

[6] Fouts, D. E., Abramovitch, R. B., Alfano, J. R., Baldo, A. M., Buell, C. R., Cartinhour, S., Chatterjee, A. K., D’Ascenzo, M., Gwinn, M. L., Lazarowitz, S. G., Lin, N. C., Martin, G. B., Rehm, A. H., Schneider, D. J., Dijk, K., Tang, X., Collmer, A. (2002): Genomewide identification of Pseudomonas syringae pv. tomato DC3000 promoters controlled by the HrpL alternative sigma factor. - Proceedings of the National Academy of Sciences of the United States of America 99(4): 2275-2280. 
[7] Frébort, I., Kowalska, M., Hluska, T., Frébortová, J., Galuszka, P. (2011): Evolution of cytokinin biosynthesis and degradation. - J. Exp. Bot. 62(8): 2431-2452.

[8] Giron, D., Frago, E., Glevarec, G., Pieterse, C. M. J., Dicke, M. (2013): Plant-MicrobeInsect Interactions. Cytokinins as key regulators in plant-microbe-insect interactions: connecting plant growth and defence. - Functional Ecology 27: 599-609.

[9] Gottig, N., Garavaglia, B. S., Garofalo, C. G., Orellano, E. G., Ottado, J. A. (2009): A filamentous hemagglutinin-like protein of Xanthomonas axonopodis pv. citri, the phytopathogen responsible for citrus canker, is involved in bacterial virulence. - PLoS ONE Journal 4(2): e4358.

[10] Hwang, M. S. H., Morgan, R. L., Sarkar, S. F., Wang, P. W., Guttman, D. S. (2005): Phylogenetic characterization of virulence and resistance phenotypes of Pseudomonas syringae. - Appl. Environ. Microbiol. 71(9): 5182-5191.

[11] Jameson, P. E. (2000): Cytokinins and auxins in plant-pathogen interactions - an overview. - Plant Growth Regul. 32: 369-380.

[12] Jin, Q. L., Thilmony, R., Zwiesler-Vollick, J., He, S. Y. (2003): Type III protein secretion in Pseudomonas syringae. - Microbes and Infection Journal 5(4): 301-310.

[13] Kakimoto, T. (2003): Biosynthesis of cytokinins. - J. Plant Res. 116(3): 233-239.

[14] Leonova, N. O. (2015): Abscisic acid and ethylene production by biotechnological strains of Bradyrhizobium japonicum. - Biotechnologia Acta 8(5): 64-70.

[15] Lindow, S. E., Brandl, M. T. (2003): Microbiology of the phyllosphere. - Appl. Environ. Microbiol. 69(4): 1875-1883.

[16] Navarro, L., Dunoyer, P., Jay, F., Arnold, B., Dharmasiri, N., Estelle, M., Voinnet, O., Jones, J. D. (2006): A plant miRNA contributes to antibacterial resistance by repressing auxin signaling. - Science 312(5772): 436-439.

[17] Nico-Liu, D. O., Ronald, P. C., Bogdanove, A. J. (2006): Xanthomonas oryzae pathovars: model pathogens of a model crop. - Molecular Plant Pathology 7(5): 303-324.

[18] Pant, G., Agrawal, P. K. (2014): Isolation and characterization of indole acetic acid production plant growth promoting rhizobacteria from rhizosperic soil of Withania somnifera. - Journal of Biological and Scientific Opinion 2(6): 373-383.

[19] Patyka, V. P., Pasichnyk, L. A. (2014): Phytopathogenic bacteria in the system of modern agriculture. - Mikrobiology Zhurnal 76(1): 21-26.

[20] Patyka, W., Gnatiuk, T., Zhytkevych, N., Kalinichenko, A., Frączek, K. (2015): Occurrence of the pathogenic bacteria Pantoea agglomerans in soybean cultivation. Progress in Plant Protection 55(3): 281-285.

[21] Pfeilmeier, S., Caly, D., Malone, J. G. (2016): Bacterial pathogenesis of plants: future challenges from a microbial perspective. - Molecular Plant Pathology 17(8): 1298-1313.

[22] Spaepen, S., Vanderleyden, J., Remans, R. (2007): Indole-3-acetic acid in microbial and microorganism - plant signaling. - FEMS Microbiology Reviews 31(4): 425-448.

[23] Woodward, A. W., Bartel, B. (2005): Auxin: regulation, action and interaction. - Ann. Bot. 95(5): 707-735.

[24] Yang, S., Zhang, Q., Guo, J., Charkowski, A. O., Glick, B. R., Ibekwe, A. M., Cooksey, D. A., Yang, Ch.-H. (2007): Global effect of indole-3-acetic acid biosynthesis on multiple virulence factors of Erwinia chrysanthemi 3937. - Appl. Environ. Microbiol. 73(4): 1079-1088.

[25] Zakharova, O., Kalinichenko, A., Dankevich, L., Patyka, V. (2015): Rapeseeds bacterial diseases and their REP-PCR analysis. - Journal of Pure and Applied Microbiology 9(1): 205-210. 